\title{
Preface to the 1998 Edition
}

In the six years since Cocaine Politics was first published, the picture it depicts of intelligence-protected drug-trafficking has emerged more and more clearly, and on a more and more alarming scale. In the last year alone, two leading CIA assets have been indicted for cocaine-smuggling. One is Venezuelan General Ramón Guillen Davila, charged by a Miami grand jury in 1996 with smuggling as much as twenty-two tons of cocaine into the United States in 1990. According to the Wall Street Journal, the CIA authorized the import of at least one ton into the United States, overruling the objections of the Drug Enforcement Administration (DEA). (Guillen claimed the agency approved all his shipments.) Many of the drugs were actually stored, prior to shipment, at a Venezuelan anti-narcotics center funded by the CIA. ${ }^{\text {' }}$

The other CIA asset indicted recently is former Haitian police chief Michel-Joseph Francois, charged with smuggling thirty-three tons of cocaine and heroin. ${ }^{2}$ Like a similarly named unit in Peru (see below), his National Intelligence Service, or SIN, functioned as what the New York Times called "an instrument of political terror." Before the CIA stopped directly supporting the unit in 1991, it gave the organization as much as $\$ 1$ million a year in equipment and training. One U.S. official said of the SIN, "It was a military organization that distributed drugs in Haiti. It never produced drug intelligence. The agency [CIA] gave them money under counternarcotics and they used their money to do other things in the political arena." ${ }^{3}$ Haiti's corrupt of ficials protected about 50 tons of cocaine a year that transited the island for the United States in the early 1990s. ${ }^{4}$

As we show in Cocaine Politics, such cases are not so much anomalous as paradigmatic. In country after country, from Mexico and Honduras to 
Panama and Peru, the CIA helped set up or consolidate intelligence agencies that became forces of repression, and whose intelligence connections to other countries greased the way for illicit drug shipments.

Although each of these cases is now public and has received scattered coverage in mainstream media, journalists (and politicians) remain reluctant to squarely address the recurring CIA-drug problem. One exception is Gary Webb, whose stories on the CIA, Contras, and cocaine (which focused on the Contra supporter Norwin Meneses: see p. 107 of this book) appeared in the San Jose Mercury News in August 1996. After they received national attention through talk radio and the World Wide Web, his stories were soon attacked, at extraordinary length, in the New York Times, Los Angeles Times, and Washington Post. Attacks on his stories soon became attacks on his personal integrity. As we go to press, Webb has been demoted from his position in the state capital of Sacramento to the small town of Cupertino. ${ }^{5}$ Webb's stories, which sketched a provocative link between the drug trafficking of Contra supporters and the crack problems of south-central Los Angeles, were admittedly controversial. Critics questioned his estimate of the amount of drugs involved, his claim that millions of dollars in profits had reached the Contras, and his case that the national crack cocaine epidemic had been created by Meneses's drug connection. But even Webb's harshest critics had to concede -as the San Francisco Examiner had first documented ten years earlierthat Meneses and his colleagues did bring large drug shipments into the country, that they did meet with top CIA Contra protèges, that they gave at least tens of thousands of dollars to the Contra cause, and that they were given extraordinary special treatment by U.S. federal prosecutors. Whatever the problems with Webb's pieces, they managed, as Peter Kornbluh wrote in the Columbia Journalism Review, to "revisit a significant story that had been inexplicably abandoned by the mainstream press, report a new dimension to it, and thus put it back on the national agenda where it belongs."6

Ironically, lost in all the squabbling over the details of Webb's stories were the abundant facts already pulled together in Cocaine Politics, which documented wider CIA (and overall Reagan Administration) protection of Central American drug traffickers. Since our book appeared, the world has also received additional information revealing just how important, and coherent, was the pattern of support for the Contras in this period from virtually all of the biggest drug cartels in the region.

For example, CIA aid for the Contras in Costa Rica was channeled chiefly through the tightly controlled Ilopango Air Base in El Salvador, a base where the real power was exercised by a U.S. colonel responsible 
for Contra support. The local DEA agent at the time, Celerino Castillo, has since charged that two hangars there, which were under CIA and Oliver North's control, doubled as depots for major cocaine shipments. Castillo claims that his documented reports on Ilopango to DEA in Washington were never acted on. ${ }^{7}$ A number of notorious drug traffickers are known to have regularly flown in and out of Ilopango; a drug plane given over to the Contras and CIA was stationed there; and Ilopango allegedly served as a base for American drug networks, such as the notorious "Company," which distributed drugs through the entire United States. ${ }^{8}$

Castillo was kept under wraps by the DEA during his service in Central America and was not called to testify before the Kerry Committee, which investigated links between the Contras, drugs, and the U.S. government in the 1980s. His firsthand account was published in Canada, but it has been almost entirely ignored by the U.S. media.

The Miami drug trial of former Panamanian strongman Manuel Noriega in 1991, after this book went to press, also supplied intriguing new details about the Central American connection. Noriega was at one time also a Contra supporter, and his initial drug indictment in 1988 was for shipments with pilots who were at the same time flying aid for Contra camps in Costa Rica. (This potentially embarrassing charge was ultimately dropped.) ${ }^{9}$

Some of the government's witnesses against Noriega provided more information than the show trial was scripted for. To quote from a 1991 Washington Post editorial, "What is one to make of the riveting assertion, made by a convicted Colombian drug kingpin at Manuel Noriega's Florida drug trial, that the Medellín cartel gave $\$ 10$ million to the Nicaraguan Contras? Carlos Lehder is a key prosecution witness; the U.S. government cannot lightly assail his credibility."10

This was not the only embarrassment for the U.S. government caused by Noriega's trial. In 1995 it was reported that one of the government's chief witnesses against Noriega, former co-defendant Ricardo Bilonick, had been paid $\$ 1.2$ million for his testimony by leaders of the Cali cartel." This confirmed our speculations that Noriega's downfall followed his having sided with the Medellín cartel against their more established competitors in Cali (see pp. 73, 82).

It has also become more clear just how cynical were the government's claims that the apprehension of Noriega would help constrain the hemispheric drug traffic. Within a year of Noriega's ouster, U.S. drug agents admitted that the Cali cartel had turned Panama into a financial and logistics base for flooding North America and Europe with cocaine. ${ }^{12}$ And 
U.S. Ambassador Deane Hinton complained in 1993 that Panamanian authorities had not arrested a single person for the crime of money laundering in the three and a half years after Noriega's capture in a bloody U.S. invasion. ${ }^{13}$

These problems are of more than historical interest, given that the problem of a U.S.-protected drug traffic endures. Today the United States, in the name of fighting drugs, has entered into alliances with the police, armed forces, and intelligence agencies of Colombia and Peru, forces conspicuous by their own alliances with drug traffickers in counterinsurgency operations.

One of the most glaring and dangerous examples is in Peru. Behind Peru's president, Alberto Fujimori, is his chief adviser Vladimiro Montesinos, the effective head of the National Intelligence Service, or SIN, an agency created and trained by the CIA in the 1960s. ${ }^{14}$ Through the SIN, Montesinos played a central role in Fujimori's "auto-coup," or suspension of the constitution, in April 1992, an event which (according to Knight-Ridder correspondent Sam Dillon) raised "'the specter of drug cartels exercising powerful influence at the top of Peru's government."15 Recently Montesinos has been accused of arranging for an opposition television station to be bombed, and in August 1996 an accused drug trafficker claimed that Montesinos had accepted tens of thousands of dollars in payoffs. ${ }^{16}$

According to an opinion column in the New York Times by Gustavo Gorriti, a leader among the Peruvian intellectuals forced into exile, "Mr. Montesinos built a power base and fortune mainly as a legal strategist for drug traffickers. He has had a close relationship with the CIA, and controls the intelligence services, and, through them, the military."17

In the New York Review of Books, Mr. Gorriti spelled out this CIAdrug collaboration more fully:

In late 1990, Montesinos also began close cooperation with the CIA, and in 1991 the National Intelligence Service began to organize a secret anti-drug outfit with funding, training, and equipment provided by the CIA. This, by the way, made the DEA ... furious. Montesinos apparently suspected that the DEA had been investigating his connection to the most important Peruvian drug cartel in the 1980s, the Rodríguez-Lopez organization, and also links to some Colombian traffickers. Perhaps not coincidentally, Fujimori made a point of denouncing the DEA as corrupt at least twice, once in Peru in 1991, and the second time at the Presiden- 
tial summit in San Antonio, Texas, in February [1992]. As far as I know, the secret intelligence outfit never carried out anti-drug operations. It was used for other things, such as my arrest. ${ }^{18}$

The San Francisco Cbronicle also reported from Mexican officials that "Vladimiro Montesinos ... and Santiago Fujimori, the president's brother, were responsible for covering up connections between the Mexican and Peruvian drug mafias." 19

Others have pointed to the drug corruption of Peru's military establishment, which also receives U.S. anti-drug funding. ${ }^{20}$ Charges that the Peruvian army and security forces were continuing to take payoffs, to protect the cocaine traffickers that they were supposed to be fighting, have led at times to a withholding of U.S. aid. ${ }^{21}$ Such charges against Fujimori, Montesinos, and the Peruvian military are completely in line with what we have written in this book about Peru over the last two decades (see pp. 84, 191).

The ongoing situation in Peru shows that Washington's proclivity to tolerate, protect, and reinforce the influence of Third World drug traffickers didn't die with the end of the Reagan-Bush years. Indeed, the Clinton Administration, guided by White House drug czar General Barry McCaffrey, has consistently asked for large increases in counternarcotics aid to compromised Latin American police and military forces. As a critical New York Times editorial observed, "Until taking the drug czar job, General McCaffrey was head of the United States army Southern Command, which worked with Latin militaries and police to fight cocaine. He knows that the overseas programs have succeeded largely in pushing cocaine from country to country."22

Such funding priorities must be repudiated. The misnamed "War on Drugs," a pernicious and misleading military metaphor, should be replaced by a medically and scientifically oriented campaign geared toward healing this country's drug sickness. The billions that have been wasted in military anti-drug campaigns, efforts which have ranged from the futile to the counterproductive, should be rechanneled into a public health paradigm, emphasizing prevention, maintenance, and rehabilitation programs. The experiments in controlled decriminalization that have been initiated in Europe should be closely studied and emulated here. ${ }^{23}$

A root cause of the governmental drug problem in this country (as distinguished from a broader social drug problem) is the National Security Act of 1947, and subsequent orders based on it. These, in effect, have exempted intelligence agencies and their personnel from the rule of 
law, an exemption that in the course of time has been extended from the agencies themselves to their drug trafficking clients. This must cease. Either the president or Congress must proclaim that national security cannot be invoked to protect drugtraffickers. This must be accompanied by clarifying orders or legislation that discourages the conscious collaboration with, or protection of, criminal drug traffickers by making it clear that such acts will constitute grounds for prosecution.

Clearly a campaign to restore sanity to our prevailing drug policies will remain utopian if it does not contemplate a struggle to realign the power priorities of our political system. Such a struggle will be difficult and painful. For those who believe in an open and decent America, the results will also be rewarding.

Notes

1 Wall Street Journal, November 22, 1996; New York Times, November 23, 1996; see also Associated Press, November 19, 1993; Washington Post, November 20, 1993. This story has a Contra connection as well: One of Guillen's associates, who was named Venezuela's 'anti-drug ambassador' in 1989 by then-President Carlos Andres Peres, reportedly worked with CIA official Duane Clarridge to funnel money to Contra leader Eden Pastora in the mid-1980s.

${ }^{2}$ San Francisco Chronicle, March 8, 1997, A10.

${ }^{3}$ New York Times, November 14, 1993.

4 Associated Press, October 14, 1993.

${ }^{5}$ For a critique of the press attack on Webb's stories, see Peter Dale Scott, "The CIA, Drugs, the Ghetto-and the Media Whitewash," Tikkun, 12, 4 (July/August 1997), 27-32.

'Columbia Journalism Review, January-February 1997, 33ff.

'Celerino Castillo, Powderburns: Cocaine, Contras, and the Drug War (Oakville, Ont.: Mosaic Press, 1994), 126, etc.

${ }^{8}$ Peter Dale Scott, "Honduras, the Contra Support Networks, and Cocaine: How the U.S. Government Has Augmented America's Drug Crisis," in War on Drugs: Studies in the Failure of U.S. Narcotic Policy, 
edited by Alfred W. McCoy and Alan A. Block (Boulder: Westview Press, 1992), 151-56. See also Sally Denton, The Bluegrass Conspiracy (New York: Avon, 1990), 332, 336-37, etc. A recently released FBI cable of July 26, 1984, pertaining to an FBI investigation of trafficking narcotics at Mena, Arkansas, corroborates widely circulated stories that convicted trafficker Barry Seal based at Mena the notorious CIA-equipped plane used in his controversial 1984 Managua "sting" operation (see Cocaine Politics, 98-102). The same plane flew in and out of Ilopango for the CIA-linked firm Southern Air Transport, and was ultimately downed by Nicaraguans in 1986, with testimony by the survivor Eugene Hasenfus then leading to the Iran-Contra Affair. See FBI cable of July 26, 1984, from Little Rock to Assistant FBI Director Revell; reproduced in R. Emmett Tyrrell, Jr., Boy Clinton: The Political Biography (Washington, D.C.: Regnery, 1996), 331-33. After the plane was downed, Revell then suspended an ongoing investigation of Southern Air Transport (Leslie Cockburn, Out of Control [New York: Atlantic Monthly Press, 1987], 231; cf. Iran Contra Report, 287). In November 1996 a CIA report acknowledged that the CIA did run "a joint training operation with another federal agency at Mena Intermountain Airport," which it also used for "routine aviation-related services" (Arkansas Democrat-Gazette, November 9,1996 ).

'New York Times, January 17, 1993, 25; Cocaine Politics, 110-11, 116.

${ }^{10}$ Washington Post, November 27, 1991, Al6.

"Washington Post, November 4, 1995 and March 5, 1996; New York Times, November 5, 1995 and March 5, 1996.

${ }^{12}$ Time, August 26, 1991. As we write, the Panamanian government is attempting to expel Peruvian journalist Gustavo Gorriti, who disclosed contributions of $\$ 51,000$ from alleged Cali representative Jose Castrillon Henao to the recent campaign of Ernesto Perez Balladares, Panama's current president. See Wall Street Journal, August 13, 1997.

${ }^{13}$ La Estrella de Panama, July 13, 1993.

${ }^{14}$ Wall Street Journal, January 28, 1997 (Montesinos); James Mills, The Underground Empire (New York: Dell, 1986), 809 (CIA).

${ }^{15}$ San Jose Mercury News, April 19, 1992.

${ }^{16}$ Wall Street Journal, January 28, 1997. The trafficker, detained in prison, later recanted his story.

${ }^{17}$ New York Times, December 27, 1992.

${ }^{18}$ New York Review of Books, June 25, 1992, 20. On the RodríguezLopez organization, see Cocaine Politics, 84, 191.

${ }^{19}$ San Francisco Chronicle, August 17, 1996. For the analogous but different situation in Colombia, see Peter Dale Scott, "Colombia: Amer- 
ica's Dirtiest War on Drugs," Tikkun (May June 1997), 27-31; Jonathan Marshall, Drug Wars (Forestville, CA: Cohan and Cohen, 1991), 17-21.

${ }^{20}$ Washington Post, May 10, 1992, A32 (Montesinos); Jonathan Marshall, Drug Wars, 24-26; Wall Street Journal, November 29, 1991; Washington Post, February 28, 1993 (military).

${ }^{21}$ New York Times, November 11, 1991, A6; September 28, 1993. (This is a reminder that Washington bureaucracies are sometimes divided over priorities and the proper choice of allies in Third World countries.)

${ }^{22}$ New York Times, July 5, 1997.

${ }^{23}$ Eva Bertram, Morris Blachman, Kenneth Sharpe, Peter Andreas, Drug War Politics: The Price of Denial (Berkeley and Los Angeles: University of California Press, 1996), 204-27. See also Marshall, Drug Wars, 63-67. 